\title{
Penggunaan Bahasa Indonesia sebagai Bahasa Sehari-hari oleh Migran di Provinsi DKI Jakarta Berdasarkan Data Sensus Penduduk 1971
}

\author{
Suyanto \\ Fakultas Ilmu Budaya, Universitas Diponegoro \\ suyanto@undip.ac.id
}

\begin{abstract}
This research is a linguistic demographic research. The focus of this study is the use of Indonesian (BI) by migrants as a colloquial language in the Province of the Special Capital Region of Jakarta based on 1971 Population Census data. This study aims: (1) to explain the number of Indonesian speakers nationally and according to ethnicity in Jakarta Province and (2) explaining the composition of migrants in Jakarta based on daily language or mother tongue. The data collection of this study uses the referral method that was developed with the technique of noting and analyzing data using descriptive statistical analysis. The results showed that the population of Indonesia was dominated by speakers of Javanese and Sundanese languages which were 40.44 percent and 15.06 percent respectively, and only 11.93 percent were Indonesian's mother tongue. The majority of migrants in Jakarta mostly use Indonesian for daily communication, which reaches 84.68 percent, and Javanese is used by 7.54 percent and third place in Sundanese is used by 3.96 percent. This conditions is far below the number of Javanese-speaking migrants who reached 41 percent and 31 percent of Sundanese. The occurrence of these symptoms is caused by: (1) the demands of work, (2) living with multilingual migrants, and (3) linguistic prestige.
\end{abstract}

Keywords: migrants, number of speakers, Indonesian, Jakarta, daily language

\section{Intisari}

Penelitian ini merupakan penelitian demografilinguistik makro. Fokus penelitian ini adalah penggunaan bahasa Indonesia (BI) oleh para migran sebagai bahasa sehari-hari di Provinsi Daerah Khusus Ibukota (DKI) Jakarta berdasarkan data Sensus Penduduk (SP) 1971. Penelitian ini bertujuan: (1) menjelaskan jumlah penutur bahasa Indonesia secara nasional dan menurut etnis di Provinsi DKI Jakarta dan (2) menjelaskan komposisi migran di DKI Jakarta berdasarkan bahasa sehari-hari atau bahasa ibu. Pengumpulan data studi ini menggunakan metode simak yang dikembangkan dengan teknik catat dan analisis data menggunakan analisis statistik deskriptif. Hasil penelitian menunjukkan bahwa penduduk Indonesia didominasi penutur bahasa Jawa dan Sunda yang masing-masing 40,44 persen dan 15.06 persen dan hanya 11.93 persen yang berbahasa ibu BI. Adapun para migran di DKI Jakarta sebagian terbesar menggunakan BI untuk komunikasi sehari-hari, yakni mencapai 84,68 persen, dan bahasa Jawa digunakan oleh 7,54 persen dan urutan ketiga bahasa Sunda digunakan oleh 3,96 persen. Angka ini jauh di bawah jumlah migran yang berbahasa ibu bahasa Jawa yang mencapai 41 persen dan bahasa Sunda 31 persen. Terjadinya gejala ini disebabkan oleh: (1) tuntutan pekerjaan, (2) tinggal bersama migran yang multibahasa, dan (3) prestis kebahasaan.

Kata kunci: migran, jumlah penutur, bahasa Indonesia, DKI Jakarta, bahasa sehari-hari 


\section{Pendahuluan}

Migrasi masuk ke ibukota Jakarta bukanlah hal baru. Hal ini telah berlangsung sejak awal Indonesia merdeka. DKI Jakarta yang menjadi pusat kekuasaan dan ekonomi dengan dukungan sarana transorportasi darat, laut dan udara yang sangat memadai menjadikannya menghipnotis penduduk dari berbagai daerah di Indonesia datang ke kota ini untuk mencari penghidupan yang lebih baik daripada di daerah asalnya. Karena keadaan itulah, kota Jakarta menjadi titik temu berbagai bidang, politik, ekonomi, dan sosial-budaya dari daerah-daerah luar Jakarta bahkan luar Indonesia. Titik temu atau persentuhan ini berdampak pada pilihan bahasa sebagai sarana komunikasi mereka yang berasal dari berbagai daerah dengan bahasa ibu yang beraneka ragam. Bahasa Indonesia merupakan satu pilihan utama alat komukasi di antara mereka.

Penelitian ini bertujuan: (1) menjelaskan perkembangan jumlah penutur bahasa Indonesia menurut etnis di Provinsi DKI Jakarta dan (2) menjelaskan komposisi penduduk DKI Jakarta berdasarkan bahasa sehari-hari.

Penelitian serupa pernah dilakukan oleh Suyanto (2011) dalam jurnal Kajian Sastra yang berjudul "Dinamika Jumlah Penutur Bahasa Indonesia: Studi Data Sensus Penduduk 1980". Dalam penelitian ini, data diperoleh dengan metode simak sedangkan analisis data menggunakan analisis statistik deskriptif berdasarkan tabel distribusi frekuensi tunggal yang dilanjutkan dengan analisis dan pemaknaan secara teoretis terhadap fenomena yang menonjol. Hasil penelitian ini menunjukkan: secara spasial penduduk di wilayah perkotaan lebih mampu menggunakan bahasa Indonesia daripada penduduk pedesaan. Di samping itu, secara kepulauan proporsi penutur bahasa Indonesia didominasi oleh Sumatera, walaupun dilihat dari angka absolut, penutur bahasa Indonesia terbanyak ada di pulau Jawa. Sedangkan berdasarkan gender menunjukkan bahwa laki-laki memiliki akses yang lebih besar dalam penguasaan bahasa Indonesia.

Penelitian lain yang masih relevan dengan penelitian ini dilakukan oleh Dinas Kependudukan dan Pencatatan Sipil Provinsi DKI Jakarta (2015) dalam buku Migrasi di Provinsi DKI Jakarta Tahun 2015. Dalam buku ini pokok permasalahan migrasi di provinsi DKI Jakarta dibagi menjadi dua yaitu (1) migrasi di Provinsi DKI Jakarta 
terdiri atas (a) mobilitas permanen dan (b) nonpermanent; (2) karakteristik migran di provinsi tersebut.

Penelitian lain yang berkaitan dengan tulisan ini adalah penelitian yang dilakukan oleh Prawiroatmodjo (1988) yang berjudul "Perkembangan Pemakaian Bahasa Indonesia Menurut Data Sensus Penduduk 1971 dan 1980”. Sesuai dengan judul penelitian, sumber data dari penelitian ini berdasarkan data Sensus Penduduk 1971 dan 1980. Menurut studi ini, tiga faktor pendorong meluasnya pemakaian bahasa Indonesia adalah (1) pendidikan, (2) perpindahan penduduk, dan (3) media massa.

Berdasarkan penelitian sebelumnya, tidak ada studi yang membahas pemakaian bahasa Indonesia sebagai bahasa sehari-hari para migran di Provinsi DKI Jakarta. Dengan demikian, penelitian ini dapat melengkapi penelitian sebelumnya.

Kerangka teori yang digunakan sebagai pisau analisis ini adalah demografilinguistik. Seperti halnya dengan demografi murni, demografilinguistik mempelajari struktur dan proses penduduk yang berfokus pada bahasa. Demografilinguistik adalah ilmu hibrida yang terdiri dari demografi dan linguistik. Dengan kata lain, demografilinguistik mengkaji bahasa yang dikaitkan dengan factor demografi. Faktor-faktor demografilinguistik terbagi menjadi dua yakni faktor statis yang meliputi (1) jumlah, (2) distribusi, dan (3) komposisi penutur serta faktor dinamis yang meliputi peristiwa dalam demografi, yaitu kelahiran, kematian, dan migrasi bahasa (Suyanto, 2017).

Migrasi memiliki pengaruh besar terhadap pemertahanan bahasa di suatu wilayah. Bahasa ibu dan bahasa kedua pada seorang migran akan mengalami semacam persaingan bahasa, sehingga akan melahirkan pergeseran atau pergantian bahasa dan pemertahanan bahasa. Dalam beberapa studi, para migran secara berangsur-angsur akan meninggalkan bahasa ibu atau bahasa nasionalnya dan beralih pada bahasa ibu atau bahasa nasional daerah/negara tujuan migrasi. Migran akan sepenuhnya menggunakan bahasa ibu atau nasional daerah atau Negara tujuan terjadi pada generasi ketiga migran tersebut (Rumbaut, 2006; Suyanto, 2017). Dengan kata lain, secara umum bahasa ibu atau nasional migran hanya memiliki harapan hidup sampai pada generasi ketiga . hal ini yang dikenal sebagai linguistic life expentancies (Rumbaut, 2006). 


\section{Metode Penelitian}

Sumber data yang digunakan dalam penelitian ini adalah hasil Sensus Penduduk Provinsi DKI Jakarta tahun 1980. Data itu meliputi (a) perkembangan penutur bahasa Indonesia menurut etnis di provinsi DKI Jakarta dan (b) komposisi penduduk DKI Jakarta berdasarkan bahasa sehari-hari. Data tersebut diperoleh menggunakan metode simak yakni dengan menyimak data secara teliti yang selanjutnya dicatat hal-hal yang relevan terkait dengan jumlah penutur BI khusus migran dan komposisi penutur BI khusus migran. Analisis data menggunakan analisis statistik deskriptif. Setelah analisis ini selesai, maka akan dikategorisasikan berdasarkan fenomena yang menonjol serta dimaknai secara teoritis.

\section{Hasil dan Pembahasan}

\section{Pertumbuhan Penduduk DKI Jakarta dan Pemakaian Bahasa Sehari-hari}

Data longitudinal menunjukkan bahwa pada tahun 1928 jumlah penduduk DKI 72.241 jiwa, naik menjadi 419.800 pada 1930. Tiga puluh satu tahun berikutnya, 1961 mengalami kenaikan menjadi 655.400 jiwa dan tahun 1971 mengalami kenaikan yang empat kali lipat lebih menjadi 2.724.659 jiwa. Sementara itu, penduduk DKI Jakarta pada tahun 1980 berjumlah 5.956 .863 jiwa. Kenaikan yang sangat signifikan dalam kurun waktu 10 tahun (1971-1980) menjadikan tahun 1980 sebagai puncak perkembangan penduduk Jakarta yang berimplikasi pada kenaikan jumlah penutur BI secara signifikan (cf. Prawiroatmodjo (1988).

Karena hidup dalam kota metropolitan yang heterogen dari segi etnis dan bahasa ibu, maka dalam komunikasi sehari-hari di antara mereka pada umumnya menggunakan bahasa Indonesia. Mereka akan menggunakan bahasa ibu masingmasing jika sedang berkomunikasi di dalam komunitas yang bahasa ibunya sama atau di ranah rumah tangga. Akan tetapi, karena sudah terkondisikan setiap saat berkomunikasi menggunakan bahasa Indonesia, maka seringkali dalam komunitas atau rumah tangga tetap menggunakan BI. Karena itulah, jumlah penduduk DKI tersebut diasumsikan sebagai penutur BI.

Berbeda dengan perkembangan jumlah penutur BI, perkembangan jumlah penutur bahasa Sunda justru mengalami penurunan.Pada tahun 1930 etnis Sunda di DKI Jakarta sebanyak 150.300 jiwa, tahun 1961 jumlah etnis Sunda naik menjadi 
952.500 jiwa, tahun 1971 mengalami penyusutan menjadi 767.413 jiwa, tahun 1980 jumlah etnis sunda justru tergerus tinggal 151.765 jiwa.

Penurunan etnis Jawa sama halnya etnis Sunda. Pada tahun 1930, etnis Jawa 60.000 jiwa, meningkat menjadi 737.700 pada tahun 1961. Pada tahun-tahun berikutnya mengalami penurunan, yakni tahun 1971 dan 1980 masing-masing 679.115 dan 235.951.

\section{Komposisi Penduduk Indonesia berdasarkan Bahasa Sehari-Hari}

Menurut bahasa yang dipakai dalam komunikasi sehari-hari (BPS, 1980an), jumlah penduduk Indonesia sebanyak 146.776.473 jiwa dan sebanyak 120.004.857 orang menggunakan delapan bahasa sebagai bahasa sehari-hari dan 26.771.616 menggunakan bahasa daerah yang lain dan tidak menjawab, seperti ditunjukkan dalam tabel berikut.

Tabel 1 Jumlah Penduduk Indonesia dan Bahasa Sehari-hari

\begin{tabular}{|l|l|r|r|}
\hline No & Bahasa sehari-hari & Jumlah & Persen \\
\hline 1 & Bahasa Indonesia & 17505303 & 11.93 \\
\hline 2 & Bahasa Jawa & 59357040 & 40.44 \\
\hline 3 & Bahasa Sunda & 22110403 & 15.06 \\
\hline 4 & Bahasa Madura & 6913977 & 4.71 \\
\hline 5 & Bahasa Batak & 3106970 & 2.12 \\
\hline 6 & Bahasa Minang & 3545928 & 2.42 \\
\hline 7 & Bahasa Bali & 2481249 & 1.69 \\
\hline 8 & Bahasa Bugis & 3322192 & 2.26 \\
\hline 9 & Bahasa Banjar & 1661795 & 1.13 \\
\hline 10 & Bahasa Daerah lain & 25653378 & 17.48 \\
\hline 11 & Tanpa keterangan & 1118238 & 0.76 \\
\hline & Jumlah & 146776473 & 100.00 \\
\hline
\end{tabular}

Sumber: BPS, 1980.

Sejumlah 25.653.378 orang memakai bahasa daerah lain dan 1.118.238 orang tidak memberi keterangan mengenai bahasanya, sehingga apabila keduanya digabungkan menjadi 26.771.616 dan dibagi 200 bahasa saja jumlahnya sudah amat kecil. Dengan kata lain, kedelapan bahasa tersebut merupakan bahasa terbesar.

Berdasarkan data di atas, jumlah penutur Bahasa Indonesia sebanyak 11,93 persen atau urutan ketiga terbanyak jumlah penduduk Indonesia saat itu. Penutur 
bahasa Jawa sangat dominan, yakni 40 persen lebih dan penutur bahasa Sunda menempati urutan kedua. Hal ini menunjukkan bahwa mereka pada umumnya dalam komunikasi sehari-hari cenderung menggunakan bahasa ibu masing-masing.

Data lain sebelum 1980, yakni data 1971 memperlihatkan bahwa persentase jumlah penutur BI jauh di atas data di atas (11,93 persen) yaitu hampir 41 persen. Jika melihat perbandingan data antarwaktu demikian, maka dat-data tentang jumlah penutur bahasa perlu divalidasi ulang karena tidak mungkin data periode berikutnya lebih kecil atau berkurang secara drastic, dari sebelumnya jumlah penutur BI mencapai hampir 41 persen dan 10 tahun berikutnya hanya dalam kisaran 12 persen. Data selengkapnya perkembangan jumlah penutur I 1928-1971 disajikan di bawah ini. Tabel 2. Perkembangan Jumlah Penduduk dan Penutur Bahasa Indonesia 1928-1990

\begin{tabular}{|l|r|r|r|}
\hline & \multicolumn{1}{|c|}{1928} & \multicolumn{1}{|c|}{1950} & \multicolumn{1}{c|}{1971} \\
\hline Penduduk & 59.100 .000 & 76.000 .000 & 118.367 .850 \\
\hline Penutur BI & 2.940 .000 & - & 48.275 .879 \\
\hline Persentase & $4,9 \%$ & - & $40.8 \%$ \\
\hline
\end{tabular}

Sumber: Suyanto, 2011 (diolah dari berbagai sumber).

Signifikannya pertumbuhan jumlah penutur bahasa Indonesia tidak lepas dari intervensi pemerintah melalui perencanaan bahasa yang dituangkan dalam politik bahasa nasional yang penggalakannya melalui pengajaran, pers, kegiatan politik, ekonomi, dan sosial (Halim, 1984). Melalui pengajaran misalnya, bahasa Indonesia menjadi subjek wajib mulai dari sekolah dasar hingga perguruan tinggi. Di dunia media massa, satu-satunya bahasa pengantar adalah bahasa Indonesia, kalaupun dijumpai media massa dalam bahasa daerah dan asing, media tersebut beredar sangat terbatas (Suyanto, 2011).

\section{Perkiraan Jumlah Migran Masuk ke Jakarta menurut Bahasa Ibu}

Untuk memperkirakan data jumlah pendatang menurut bahasa daerahnya digunakan data jumlah penduduk yang telah mendaftarkan diri ke kantor Dinas Pendaftaran Kependudukan dalam kurun waktu 1971 hingga 1983. Akan tetapi, migran yang mendaftar diri hanya berjumlah 336.671 atau 13 persen dari seluruh migran masuk ke DKI Jakarta, maka data di bawah ini hanya merupakan contoh perkiraan seluruh jumlah migran masuk menurut asal provinsi mereka. 
Tabel 3. Perkiraan Jumlah Migran Masuk di DKI Jakarta menurut Daerah Asal Tahun 1971

\begin{tabular}{|l|r|r|}
\hline \multicolumn{1}{|c|}{ Provinsi Asal } & \multicolumn{1}{c|}{ Jumlah } & \multicolumn{1}{c|}{ Presen } \\
\hline Sumatera Utara & 131.774 & 5,0 \\
\hline Sumatera Barat & 79.000 & 3,0 \\
\hline Jawa Barat & 817.003 & 41,0 \\
\hline Jawa & 1.080 .552 & \\
Tengah/Timur/Yogya & & 1,0 \\
\hline Madura* & 73.375 & 3,0 \\
\hline Bali & 26.355 & 4,0 \\
\hline Sulawesi & 79.065 & 12,0 \\
\hline Kalimantan & 105.420 & 100,0 \\
\hline Lain-lain & 316.259 & \\
\hline Jumlah & 2.635 .493 & \\
\hline
\end{tabular}

Sumber: Prawiroadmodjo, 1988 (diolah).

*22,0 persen dari penduduk Provinsi Jawa Timur.

Data di atas memperlihatkan bahwa migran asal Jawa Tengah/Timur/Jogjakarta paling dominan, yakni sebesar 41 persen dari seluruh migran masuk ke DKI Jakarta. Data di atas adalah jumlah migran yang dalam komunikasi sehari-hari tetap mempertahankan bahasa ibu sebagai sarana komunikasi. Akan tetapi, sekali lagi, karena pendataan hanya berdasar migran masuk yang mendaftar ke pemerintah, maka data itu sebenarnya belum mencerminkan kondisi riil. Fenomena migrasi di Indonesia selalu menunjukkan bahwa migrasi ilegal lebih besar daripada migrasi legal. Dalam kasus ini, jumlah migran masuk yang tidak mendaftarkan diri sebenarnya jauh lebih besar daripada mereka yang mendaftarkan diri.

Jumlah migran masuk ke DKI Jakarta terbanyak kedua adalah dari Jawa Barat. Migran asal Jawa Barat menempati urutan kedua merupakan suatu kewajaran karena dari segi geografis, Jawa Barat berbatasan langsung dengan DKI Jakarta. Bahkan secara riil bisa jadi migran terbanyak ke Jakarta berasal dari daerh ini. setiap hari, penduduk Jawa Barat di perbatasan melakukan migrasi ualng alik (nglaju) dengan berangkat pagi pulang sore atau malam, mingguan dan mungkin bulanan (mondok).

Berdasarkan sensus penduduk 1971 penduduk Jakarta berjumlah 4.546.492, dan dari jumlah tersebut 1.866 .635 adalah pendatang baru, atau 41persen dari seluruh penduduk. Dan dari jumlah tersebut 1.418 .812 orang meninggalkan bahasa asalnya dan menggunakan bahasa Indonesia sebagai alat perhubungan sehari- 
harinya. Dan sisanya, 447.823 orang mempertahankan bahasa daerah asalnya atau 23,99 persen (Prawiroatmodjo, 1988).

Walaupun migran paling dominan di Jakarta berbahasa ibu bahasa Jawa dan Sunda yang mencapai 71 persen, namun sebagian besar di antara mereka menggunakan BI sebagai bahasa sehari-hari, hanya tersisa 10 persen di antara mereka yang masih setia menggunakan bahasa ibunya dalam komunikasi seharihari. Gejala ini disebabkan oleh minimal tiga faktor yaitu (1) tuntutan pekerjaan, (2) tinggal bersama migran yang multibahasa, (3) prestis kebahasaan. Pertama, para migran pada umumnya bekerja dalam lingkungan yang menggunakan bahasa Indonesia, baik mereka yang bekerja di ranag rumah tangga maupun public (perkantoran). Migran yang bekerja di sektor domestik (rumah tangga), pada umumnya bekerja dengan majikan dari etnis/ras lain atau sama etnis namun majikan mereka masuk kategori kelas menengah ke atas. Rumah tangga -rumah tangga yang mempekerjakan pembantu rumah tangga (asisten rumah tangga) umumnya merupakan keluarga terpelajar yang bekerja atau berusaha di lingkungan modern yang menuntuk penggunaan BI dalam komunikasi sehari-hari. Kebiasaan ini, walaupun mereka berbahasa ibu sama dengan pembantunya seringkali berkomunikasi dengan mengguankan BI. Kedua, tidak jarang migran yang bekerja di sektor publik dan tinggal bersama migran yang berasal dari bahasa ibu yang beragam. Kemultibahasaan migran yang tinggal bersama sudah barang tentu menuntut penggunaan bahasa yang dikuasai oleh mereka secara bersama-sama. Bahasa yang dikuasai oleh migran yang beragam bahasa ibunya sudah barang tentu pilihannya adalah BI. Ketiga, pemilihan BI sebagai bahasa komunikasi sehari-hari bagi migran dari berbagai bahasa ibu yang berbeda-beda disebabkan prestis BI yang lebih tinggi daripada bahasa ibu masing-masing. Para migran memahami bahwa semakin tinggi status sosial ekonomi seseorang akan memeiliki kecenderungan hidup secara modern. Salah satu kemodernan ditandai adanya pemakaian bahasa nasional, yakni BI. Bahkan tidak jarang para migran (pembantu rumah tangga, buruh, pekerja) ketika baru saja pulang kampung halaman masih tetap mengguankan BI untuk menunjukkan bahwa dirinya adalah orang yang lebih modern dari pada tetanga atau teman-temannya di desa karena baru saja pulang 
dari Jakarta. Di bawah ini ditunjukkan jumlah migran berdasar bahasa ibu dan bahasa sehari-hari di Jakarta.

Tabel 4. Migran di DKI Jakarta menurut Bahasa Sehari-hari Tahun 1971

\begin{tabular}{|l|r|r|}
\hline \multicolumn{1}{|c|}{ Bahasa } & \multicolumn{1}{c|}{ Jumlah Penutur } & \multicolumn{2}{c|}{ Persentase } \\
\hline Bahasa Indonesia & 2.231 .756 & 84,68 \\
\hline Jawa & 198.729 & 7,54 \\
\hline Sunda & 104.248 & 3,96 \\
\hline Madura & 2.046 & 0,08 \\
\hline Batak & 18.032 & 0,70 \\
\hline Minang & 23.724 & 0,90 \\
\hline Bali & 474 & 0,02 \\
\hline Bugis & 2.164 & 0,08 \\
\hline Banjar & 157 & 0,00 \\
\hline Lain-lain & 53.433 & 2,00 \\
\hline Tidak terjawab & 130 & 0,00 \\
\hline Jumlah & 2.635 .493 & 100,00 \\
\hline Sumbr: BPS, & & \\
\hline
\end{tabular}

Sumber: BPS, 1971.

Selain itu, menurut teori harapan hidup sebuah bahasa (Rumbaut, et al. 2006) bahwa bahasa ibu pada umumnya masih dikuasai dan dipergunakan dalam komunikasi sehari-hari oleh migran generasi pertama (migran yang lahir di wilayah bahasa ibunya), generasi kedua sudah secara berimbang dalam penguasaan dan penggunaan antara bahasa ibu generasi pertama dengan bahasa yang dipergunakan di daerah atau wilayah tujuan, dan generasi ketiga akan menjadi penutur monolingual bahasa yang sehari-hari dipergunakan di wilayah tujuan migrasi. Skema pergeseran dan harapan hidup sebuah bahasa di kalangan migran ditunjukkan di bawah ini.

Skema.1 Harapan Hidup sebuah Bahasa

\begin{tabular}{|c|c|c|c|}
\hline \multicolumn{4}{|c|}{ NASIONAL } \\
\hline \multirow{4}{*}{$\mathbf{A} \rightarrow \mathbf{B}$} & Generasi I & Generasi II & Generasi III \\
\cline { 2 - 4 } & monolingual & bilingual & monolingual \\
\cline { 2 - 4 } & bilingual & bilingual & monolingual \\
\cline { 2 - 4 } & A $>$ B & B > A & B \\
\hline
\end{tabular}

\section{Simpulan}

Berdasarkan pembahasan di atas dapat diringkas beberapa hal. Pertama, penduduk Indonesia didominasi penutur bahasa Jawa dan Sunda yang masing-masing 40,44 
persen dan 15.06 persen dan hanya 11.93 persen yang berbahasa ibu BI. Kedua, migrasi masuk di DKI Jakarta didominasi oleh penutur asli (bahasa ibu) bahasa Jawa yang mencapai 41 persen dan bahasa Sunda 31 persen. Ketiga, walau demikian para migran di DKI Jakarta sebagian terbesar menggunakan BI untuk komunikasi seharihari, yakni mencapai 84,68 persen, dan bahasa Jawa digunakan oleh 7,54 persen dan bahasa Sunda digunakan oleh 3,96 persen. Bergesernya pilihan penggunaan bahasa ibu ke bahasa nasional (BI) para migran disebabkan oleh tiga faktor yaitu (1) tuntutan pekerjaan, (2) tinggal bersama migran yang multibahasa, (3) prestis kebahasaan. Berdasarkan temuan tersebut dapat dismpulkan bahwa bahasa ibu pada umumnya masih dikuasai dan dipergunakan dalam komunikasi sehari-hari oleh migran generasi pertama (migran yang lahir di wilayah bahasa ibunya) dan jika bahasa ibu tidak dipergunakan karena tuntutan situasi yang menghendaki pemakaian bahasa nasional atau bahasa daerah tjuan, generasi kedua sudah secara berimbang dalam penguasaan dan penggunaan antara bahasa ibu generasi pertama dengan bahasa yang dipergunakan di daerah atau wilayah tujuan untuk semua kepentingan dan ranah, dan generasi ketiga akan menjadi penutur monolingual bahasa yang sehari-hari dipergunakan di wilayah tujuan migrasi.

\section{Daftar Pustaka}

Adiwoso, Riga. 1988. "Permasalahan Data Statistik di Indonesia: Penggunaan Indeks Komunikasi terhadap Sensus Penduduk 1980”. Jurnal Linguistik Indonesia 6 (11): 114.

Budhisantoso, S. dkk. TT. Alat Penjaja Tradisional Daerah Khusus Ibukota Jakarta. Jakarta: Departemen Pendidikan dan Kebudayaan.

Dinas Kependudukan dan Pencatatan Sipil Provinsi DKI Jakarta. 2015. Migrasi Penduduk di Provinsi DKI Jakarta Tahun 2015.

Ferguson, C.A. 1959. "Diglossia” dalam Word, volume 15, pp 325-340.

Graddol, David. "The Future of Language". Jurnal American Association for the Advancement of Science 303 (5662): 1329-1331.

Halim, Amran. 1984. Politik Bahasa Nasional 1. Jakarta: PN Balai Pustaka.

Haryono, Inny C. 1988. "Pemakaian Bahasa Indonesia oleh Masyarakat Cina di Indonesia dalam Kurun Waktu 20-tahun Terakhir". Jurnal Linguistik Indonesia 6 (11): 39-48.

Kesuma, Tri Mastoyo Jati. 2007. Pengantar (Metode) Penelitian Bahasa. Yogyakarta: Carasvatibooks. 
Mantra, Ida Bagus. 2003. Demografi Umum. Yogyakarta: Pustaka Pelajar.

Muhadjir. 1988. "Pergeseran dan Pemertahanan Beberapa Bahasa Daerah di Jakarta". Jurnal Linguistik Indonesia 6 (11): 49-62.

Prawiroatmodjo, Basuki Suhardi. 1988. "Perkembangan Pemakaian Bahasa Indonesia Menurut Sensus Penduduk 1971 dan Sensus Penduduk 1980”. Jurnal Linguistik Indonesia 6 (11): 27-38.

Romdiati, Haning dan Mita Noveria. 2006. "Mobilitas Penduduk Antardaerah dalam Rangka Tertib Pengendalian Migrasi Masuk ke DKI Jakarta". Jurnal Kependudukan Indonesia 1 (1): 13-28.

Rumbaut, Ruben G. et al. 2006. "Linguistic Life Expectancies: Immigrant Language Retention in Southern California". Jurnal Population Council 32 (3): 447-460.

Suyanto. 2011. "Dinamika Penutur Bahasa Indonesia: Studi Data Sensus Penduduk 1980". Jurnal Kajian Sastra, Vol. 35 (1), 2011. 